\title{
Increase of NKG2D ligands and sensitivity to NK cell-mediated cytotoxicity of tumor cells by heat shock and ionizing radiation
}

\author{
Joo-Young $\mathrm{Kim}^{1,4}$, Young-Ok Son ${ }^{7}$, \\ Soon-Won Park', Jae-Ho Bae ${ }^{1,4}$, \\ Joo Seop Chung ${ }^{2,5}$, Hyung Hoi $\mathrm{Kim}^{3}$, \\ Byung-Seon Chung ${ }^{1}$, Sun-Hee Kim ${ }^{1,4,5,6,8}$ \\ and Chi-Dug Kang ${ }^{1,5,6,8}$
}

${ }^{1}$ Department of Biochemistry

${ }^{2}$ Department of Internal Medicine

${ }^{3}$ Department of Laboratory Medicine

${ }^{4}$ Medical Research Center for Ischemic Tissue Regeneration

Pusan National University School of Medicine

${ }^{5}$ Busan Regional Cancer Center

Pusan National University Hospital

${ }^{6}$ Medical Research Institute

Pusan National University

Busan 602-739, Korea

${ }^{7}$ Research and Development Center

BINEX Co., LTD.

Busan 604-846, Korea

${ }^{8}$ Corresponding authors: Tel, 82-51-240-7738 (SH Kim);

82-51-240-7739 (CD Kang);

Fax, 82-51-248-1118 (SH Kim; CD Kang);

E-mail, ksh7738@pusan.ac.kr (SH Kim);

kcdshbw@pusan.ac.kr (CD Kang)

Accepted 18 July 2006

Abbreviations: MICA/B, MHC class I-related chain A and B; ULBPs, UL-16 binding proteins

\begin{abstract}
In this study, we have investigated if current cancer therapeutic modalities including hyperthermia and ionizing radiation can increase the expression of NKG2D ligands in human cancer cell lines. The expressions of NKG2D ligands were induced by both heat shock and ionizing radiation in various cell lines including $\mathrm{KM} 12, \mathrm{NCl}-\mathrm{H} 23$, HeLa and A375 cells with peaks at $2 \mathrm{~h}$ and $9 \mathrm{~h}$ after treatment, respectively, although inducibility of each NKG2D ligand was various depending on cell lines. During the induction of NKG2D ligands, heat shock protein 70 was induced by heat shock but not by ionizing radiation. These results were followed by increased susceptibilities to NK cell-mediated cytolysis after treatment with heat shock and ionizing radiation. These results suggest that heat shock and ionizing radiation
\end{abstract}

induce NKG2D ligands and consequently might lead to increased NK cell-mediated cytotoxicity in various cancer cells.

Keywords: heat-shock response; immunotherapy, active; killer cells, natural; natural killer cell activating receptors; neoplasms; radiation, ionizing

\section{Introduction}

Based on the discovery and identification of tumorassociated antigens, it is now possible to target tumors specifically by cytotoxic T lymphocytes (CTLs) (Rosenberg, 1999). However, major histocompatibility complex (MHC) class I molecule expression is known to be reduced in many malignant tumors permitting escape from immune surveillance by MHC-restricted CTLs (Amiot et al., 1998). Meanwhile, tumors lacking MHC class I expression become more susceptible to NK cells (Pawelec, 2004). Although NK cells can mediate in part an antitumor immunity induced by dendritic cell vaccination (Kim et al., 2004a), they can recognize target cells such as tumor cells and virally infected cells without need for immunization or pre-activation compared with $T$ cells, which first require activation by antigen-presenting cells (Smyth et al., 2002; Albertsson et al., 2003; Colucci et al., 2003).

NK cell-mediated killing of tumor cells is result of integration of signals from several activating and inhibitory receptors that are regulated by the density and selection of class I and class-I like ligands expressed by the target cell (Farag et al., 2003). The best characterized activating ligands are the NKG2D ligands, in which $\mathrm{MHC}$ class I-related chain $\mathrm{A}$ and $\mathrm{B}$ (MICA/B) have been known to be induced by cellular distresses such as heat shock, oxidative stress and viral infection, and UL-16 binding proteins (ULBPs) by viral infection (Vivier et al., 2002; Farag and Caligiuri, 2006). Feature of the different NKG2D ligands is their stress-inducible expression and their specific presence on different tumor cell lines (Watzl, 2003).

The ability of NKG2D ligands to specifically "mark" stressed or transformed cells suggests that the susceptibility of tumor cells to NK cells may be controlled by the regulated expression of activating ligands. Since expression of NKG2D ligands can render target cells sensitive to NK cell attack, tumor cells that express normal level of MHC class I and 
high level of NKG2D ligands at the cell surface may still be killed by autologous NK cells (Raulet, 2003). Therefore, modulation of NKG2D ligands expression may be an attractive strategy for controlling tumor development and progression.

Local radiation therapy could increase the expression of immunologically important cellular proteins on tumor cells (Santin et al., 1998), and consequently alter immunogenicity of the tumor cells. Recently, it has been shown that radiation of malignant tumor cells enhanced killer cell-mediated cytotoxicity in autologous models (Ishikawa et al., 2004). In addition, hyperthermia is one of the promising approaches in cancer therapy. Among NKG2D ligands, MICA/B have been known to be induced by heat shock (Groh et al., 1996).

Here, we investigated whether heat shock and ionizing radiation can increase the expression of NKG2D ligands in human cancer cell lines and consequently enhance their susceptibility to NK cell-mediated cytotoxicity.

\section{Materials and Methods}

\section{Cell lines}

The A375 human melanoma cells (kindly provided by Dr. I. J. Fidler, M.D. Anderson Cancer Center, Houston), which were originally established from a lymph node metastasis of melanoma, and KM12 cells, which were isolated from a primary colon carcinoma classified as Dukes' stage B2, were maintained at $37^{\circ} \mathrm{C}$ in a $5 \% \mathrm{CO}_{2}$ incubator in DMEM supplemented with $10 \%$ fetal bovine serum (GibicoBRL Life Technologies Inc., Gaithersburg, MD), streptomycin $(100 \mu \mathrm{g} / \mathrm{ml})$, and penicillin $(100 \mathrm{U} / \mathrm{ml})$. The human non-small cell lung cancer cell line $\mathrm{NCl}-\mathrm{H} 23$ and human cervical carcinoma cell line HeLa were obtained from the American Type Culture Collection (ATCC, Rockville, MD) and maintained in RPMI 1640 supplemented with $10 \%$ fetal bovine serum and antibiotics at $37^{\circ} \mathrm{C}$ in a $5 \% \mathrm{CO}_{2}$ incubator.

\section{Multiplex reverse transcription-PCR analysis}

The presence of NKG2D ligands was examined by multiplex RT-PCR analysis (Park et al.). Total RNA was extracted using RNeasy mini kit (Qiagen, Valencia, CA). One microgram of extracted total RNA was used to synthesize cDNA. 100 pmol of random primers (Takara Shuzo, Shiga, Japan) and $2.5 \mathrm{mM}$ of each deoxynucleotide triphosphate were added and incubated at $65^{\circ} \mathrm{C}$ for $5 \mathrm{~min}$, and quickly chilled on ice. This mixture was combined with 250 $\mathrm{mM}$ Tris- $\mathrm{HCl}, 375 \mathrm{mM} \mathrm{KCl}, 50 \mathrm{mM}$ DTT, $15 \mathrm{mM}$ $\mathrm{MgCl}_{2}$ and $100 \mathrm{U}$ of $\mathrm{M}-\mathrm{MLV}$ reverse transcriptase (Promega Co.) and incubated at $37^{\circ} \mathrm{C}$ for $50 \mathrm{~min}$. The resulting CDNA was used for PCR reaction with QIAGEN multiplex PCR kit (Qiagen $\mathrm{GmbH}$, Germany) using PCR primers listed in Table 1. The conditions for multiplex PCR were $15 \mathrm{~min}$ at $95^{\circ} \mathrm{C}$, 29 cycles of $30 \mathrm{sec}$ at $94^{\circ} \mathrm{C}, 90 \mathrm{sec}$ at $65^{\circ} \mathrm{C}$, and 90

Table 1. List of primers used in multiplex RT-PCR.

\begin{tabular}{|c|c|c|c|c|}
\hline Name & Polarity & Sequence $\left(5^{\prime} \rightarrow 3^{\prime}\right)$ & Position of primer & $\begin{array}{l}\text { Size of } \\
\text { amplicon }\end{array}$ \\
\hline GAPDH & $\begin{array}{l}\text { Sense } \\
\text { Anti-sense }\end{array}$ & $\begin{array}{l}\text { CCTCCCGCTTCGCTCTCTGC } \\
\text { GGGTGGCAGTGATGGCATGG }\end{array}$ & $\begin{array}{c}17-36 \\
637-656\end{array}$ & 640 bp \\
\hline RPL19 & $\begin{array}{l}\text { Sense } \\
\text { Anti-sense }\end{array}$ & $\begin{array}{l}\text { ATGCTCAGGCTTCAGAAGAGGCTCG } \\
\text { TGATGATCTCCTCCTTCTTGGCCTG }\end{array}$ & $\begin{array}{c}16-40 \\
541-565\end{array}$ & 550 bp \\
\hline MICA & $\begin{array}{l}\text { Sense } \\
\text { Anti-sense }\end{array}$ & $\begin{array}{l}\text { TTGAGCCGCTGAGAGGGTGGC } \\
\text { GGGAGAGGAAGAGCTCCCCATC }\end{array}$ & $\begin{array}{c}7-27 \\
445-466\end{array}$ & 460 bp \\
\hline МICB & $\begin{array}{l}\text { Sense } \\
\text { Anti-sense }\end{array}$ & $\begin{array}{l}\text { GCCCCCTGACCCCTTGTTCC } \\
\text { GGGCTGGTCAACTTGGCGAAA }\end{array}$ & $\begin{array}{l}1648-1667 \\
1985-2005\end{array}$ & 358 bp \\
\hline ULBP1 & $\begin{array}{l}\text { Sense } \\
\text { Anti-sense }\end{array}$ & $\begin{array}{l}\text { TGGCTGGTCCCGGGCAGGAT } \\
\text { GAATGTCAAGCAGTTGCCCTTTAAGGAAA }\end{array}$ & $\begin{array}{c}60-79 \\
297-325\end{array}$ & 266 bp \\
\hline ULBP2 & $\begin{array}{l}\text { Sense } \\
\text { Anti-sense }\end{array}$ & $\begin{array}{l}\text { TCAAACTCGCCСTTCTGTCTGGC } \\
\text { GCAGGAATTCCATCAGGTAGCACCA }\end{array}$ & $\begin{array}{c}879-901 \\
1048-1072\end{array}$ & 194 bp \\
\hline ULBP3 & $\begin{array}{l}\text { Sense } \\
\text { Anti-sense }\end{array}$ & $\begin{array}{l}\text { AGGTCTTATCTATGGGTCACCTAGAAG } \\
\text { TGAAATCCTCCAGCTCAGTGTCAGC }\end{array}$ & $\begin{array}{l}212-238 \\
319-343\end{array}$ & 132 bp \\
\hline ACTB & $\begin{array}{l}\text { Sense } \\
\text { Anti-sense }\end{array}$ & $\begin{array}{l}\text { TCCATCCTGGCCTCGCTGTC } \\
\text { GCATTTGCGGTGGACGATGG }\end{array}$ & $\begin{array}{l}1103-1122 \\
1176-1195\end{array}$ & $93 \mathrm{bp}$ \\
\hline
\end{tabular}


sec at $72^{\circ} \mathrm{C}$ with a final elongation step of $5 \mathrm{~min}$ at $72^{\circ} \mathrm{C}$. The PCR products were analyzed by ethidium bromide-stained $2.0 \%$ agarose gel electrophoresis.

\section{Heat shock treatment}

Heat shock treatment was carried out as described previously (Groh et al., 1998). Briefly, tumor cell lines grown in $10-\mathrm{cm}$ culture dishes were immersed in a $42^{\circ} \mathrm{C}$ water bath for $60 \mathrm{~min}$, followed by incubation at $37^{\circ} \mathrm{C}$ for various lengths of time, and then subjected to PCR analysis.

\section{Treatment with gamma-radiation}

Tumor cell lines were irradiated with $20 \mathrm{~Gy}$ in culture dishes using ${ }^{137} \mathrm{Cs}$ source blood irradiator (Gammacell 3000 Elan, MDS Nordion, Ottawa, Canada) at a dose rate $5 \mathrm{~Gy} / \mathrm{min}$, followed by incubation at $37^{\circ} \mathrm{C}$ for various lengths of time, and then subjected to PCR analysis.

\section{Flow cytometric analysis}

To determine the surface expression of the NKG2D ligands on the tumor cell lines, the following monoclonal antibodies (mAbs) were used: the anti-human MICA and B mAbs were from Immatics biotechnologies $\mathrm{GmbH}$ (Tubingen, Germany), and antiULBP1,2,3 mAbs were from R\&D Systems (Wiesbaden, Germany). Cells were incubated with each anti-NKG2D ligand $\mathrm{mAb}$ or isotype control at 10 $\mu \mathrm{g} / \mathrm{ml}$ and then, after washing, with goat anti-mouse Ig FITC conjugate (1:100) (Becton Dickinson Immunocytometry Systems, CA) as secondary reagent. To determine the surface expression of HLA Class I, cells $\left(1 \times 10^{6}\right)$ were incubated at $4^{\circ} \mathrm{C}$ for $30 \mathrm{~min}$ with FITC-conjugated anti-HLA Class I mAb (W6/32) (Sigma, St. Louis, MO). Samples were analyzed on a FACSCalibur (BD Becton Dickinson Biosciences, Heidelberg) with CellQuest software (BD PharMingen Becton Dickinson, Mountain View, CA).

\section{Preparation of NK cells}

NK cells were isolated from PBMC of healthy donors with NK Cell Isolation Kit II (MACS system, Miltenyi Biotech, Bergisch Gladbach, Germany). Briefly, human mononuclear cells were isolated from healthy volunteers by Ficoll-Hypaque density centrifugation (Sigma, St. Louis, MO) and were incubated in RPMI1640 supplemented with $10 \%$ heat-inactivated FBS, 2 mM L-glutamine, $50 \mu \mathrm{M}$ 2-mercaptoethanol, $100 \mathrm{U} / \mathrm{ml}$ penicillin and $100 \mu \mathrm{g} / \mathrm{ml}$ streptomycin for 2 $\mathrm{h}$ at $37^{\circ} \mathrm{C}$ to remove adherent cells. $10 \mu \mathrm{l}$ of Biotin Antibody Cocktail was added to $1 \times 10^{7}$ cells in 40 $\mu$ of MACS buffer, and the mixture was incubated at $4^{\circ} \mathrm{C}$ for $10 \mathrm{~min} .30 \mu \mathrm{l}$ of MACS buffer and $20 \mu \mathrm{l}$ of Anti-Biotin MicroBeads were added and the mixture was incubated at $4^{\circ} \mathrm{C}$ for $15 \mathrm{~min}$. After washing with MACS buffer, NK cells were negatively selected using a LS Column with a VarioMACS Separator system. The isolated cells henceforth referred to as NK cells were more than $90 \%$ CD56 positive. The freshly separated NK cells were cultured at a concentration of $1 \times 10^{6}$ cells $/ \mathrm{ml}$ in culture medium containing $200 \mathrm{IU} / \mathrm{ml}$ recombinant human interleukin-2 (Chiron Corporation, Emeryville, Calif.) for 5 days.

\section{${ }^{51}$ Cr-release assay}

Cytotoxicity was determined with a standard ${ }^{51} \mathrm{Cr}$ release assay. One million target cells were labeled at $37^{\circ} \mathrm{C}$ for $1 \mathrm{~h}$ with $100 \mu \mathrm{Ci} \mathrm{Na} 2{ }^{51} \mathrm{CrO}_{4}$ (Amersham Pharmacia, Piscataway, NJ). Cells were washed and resuspended at cell density of $1 \times 10^{5} \mathrm{cells} / \mathrm{ml}$ with RPMI1640 complete medium. Effector and target $\left(5 \times 10^{3}\right)$ cells were placed into individual wells of 96-well U-bottom plates (NUNC ${ }^{\text {TM }}$, Nalge Nunc International, Denmark) in a total volume of $200 \mu \mathrm{l}$. Cytotoxicity assays were performed at $37^{\circ} \mathrm{C}$ for $4 \mathrm{~h}$. After incubation, aliquots were analyzed with a gamma counter (LKB-Wallac CliniGamma 1272, Wallac, Finland). The maximum or spontaneous release was defined as counts from samples incubated with $2 \%$ Triton-X or medium alone, respectively. "Specific cytotoxicity" was calculated as the measure of NK function against each target. Percentage specific lysis was calculated using the following formula: (experimental release-spontaneous release)/(maximum release-spontaneous release) $\times$ $100 \%$.

\section{Statistics}

For comparison of groups, unpaired Student's $t$ test was performed. $P<0.05$ was considered significant in all experiments.

\section{Results}

\section{Induction of NKG2D ligands by heat shock in various human cancer cell lines}

To investigate the effect of heat shock on the expression of NKG2D ligands, total RNA was isolated from various tumor cell lines treated with heat shock and subjected to multiplex RT-PCR (Figure 1). In $\mathrm{KM} 12, \mathrm{NCl}-\mathrm{H} 23$ and HeLa cells, treatment with heat shock resulted in increase of the levels of all NKG2D ligands. The levels of NKG2D ligands were increased in a time-dependent manner, and reached the 

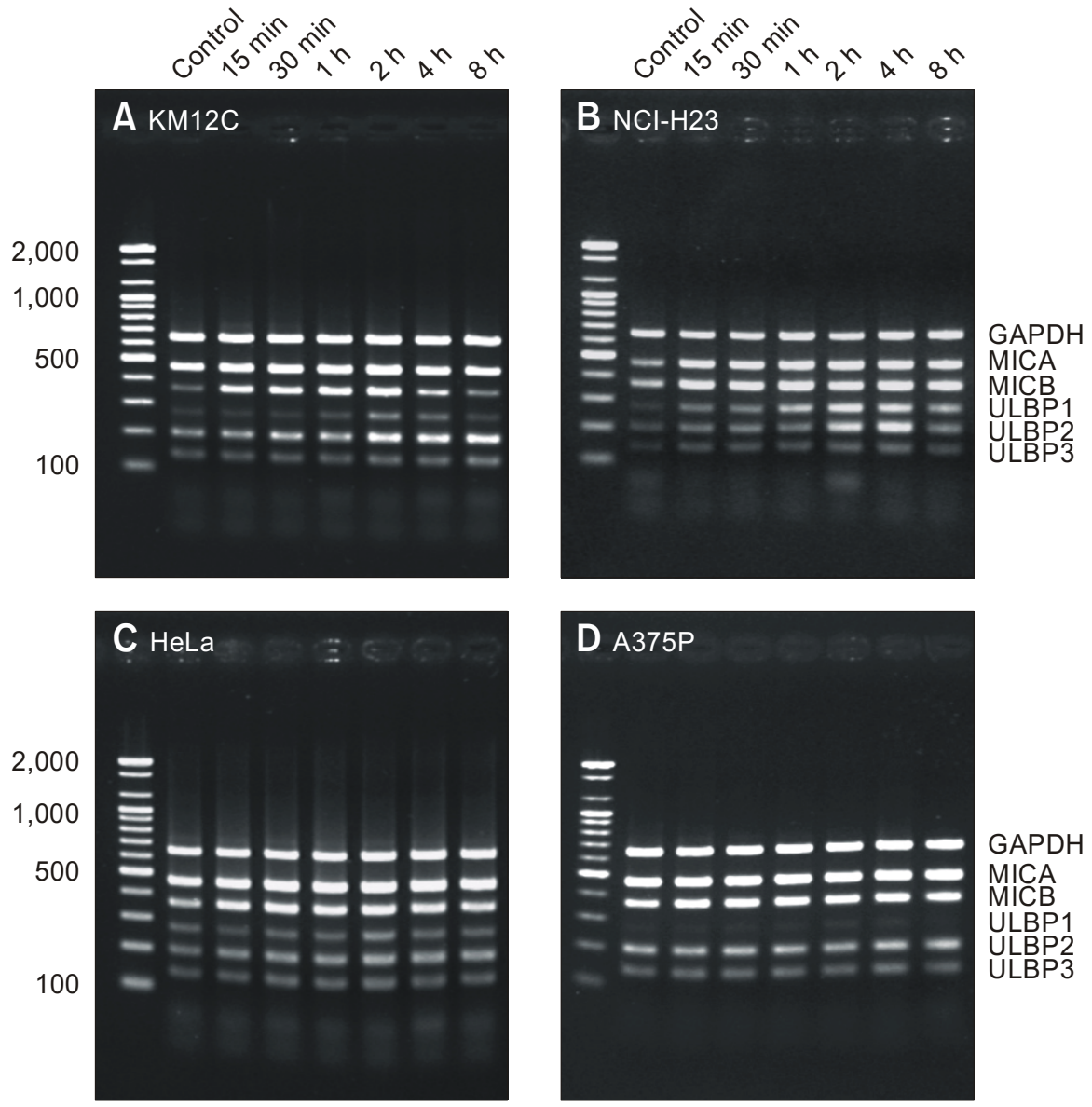

Figure 1. Induction of NKG2D ligands in human cancer cell lines by heat shock treatment. Each human cancer cell line was treated with heat shock $(1 \mathrm{~h}$ exposure to $42^{\circ} \mathrm{C}$ ), and allowed to recover at $37^{\circ} \mathrm{C}$ for the indicated time. Total RNA was isolated and then subjected to multiplex RT-PCR analysis for expression of NKG2D ligands including MICA, MICB, ULBP1, ULBP2 and ULBP3. (A) KM12: human colon carcinoma cells, (B) NClH23: human non-small cell lung carcinoma cells, (C) HeLa: human cervical carcinoma cells and (D) A375: human melanoma cells.

maximum levels at approximately 2-4 $\mathrm{h}$ after heat shock. Among NKG2D ligands, MICB and ULBP2 appeared to respond most sensitively to heat shock. Meanwhile, in A375 cells, which barely expressed ULBP1, only MICB seemed to be induced by heat shock. The results demonstrated that heat shock treatment induced not only MICA/B but also ULBPS in tumor cells, although inducibilities of NKG2D ligands by heat shock were somewhat different among various tumor cells.

\section{Induction of NKG2D ligands by ionizing radiation in various human cancer cell lines}

In addition to heat shock, it was studied if ionizing radiation, which is commonly used to treat cancer, can induce NKG2D ligands in cancer cell lines (Figure 2). In KM12 and HeLa cells, treatment with ionizing radiation resulted in increase of the levels of MICB, ULBP1 and 2. The levels of these NKG2D ligands were increased in a time-dependent manner, and peaked at approximately $9 \mathrm{~h}$ after ionizing radiation. In $\mathrm{NCl}-\mathrm{H} 23$ and $\mathrm{A} 375 \mathrm{P}$ cells, ULBP1, and MICB and ULBP2 were increased slightly by ionizing radiation, respectively. These results showed that ionizing radiation also can upregulate the expression of NKG2D ligands.

\section{Surface expression of NKG2D ligands after heat shock and ionizing radiation}

We examined with flow cytometric analysis if the increased transcription of NKG2D ligands genes is followed by increased surface expression of NKG2D ligands. Since $\mathrm{NCl}-\mathrm{H} 23$ and Hela cells appeared to respond most sensitively to heat shock and ionizing radiation, respectively, the surface expression of NKG2D ligands was monitored in $\mathrm{NCl}-\mathrm{H} 23$ cells after treatment with heat shock (Figure $3 \mathrm{~A}$ ) and in Hela cells after treatment with ionizing radiation (Figure 3B). The surface expression of NKG2D ligands were increased by heat shock time-dependently with peak after $4 \mathrm{~h}$, and also increased by ionizing radiation time-dependently up to $24 \mathrm{~h}$. Although the surface expression of NKG2D ligands was not exactly in proportion to their mRNA levels, the increased level of mRNA of NKG2D ligands induced by heat shock and ionizing radiation was 

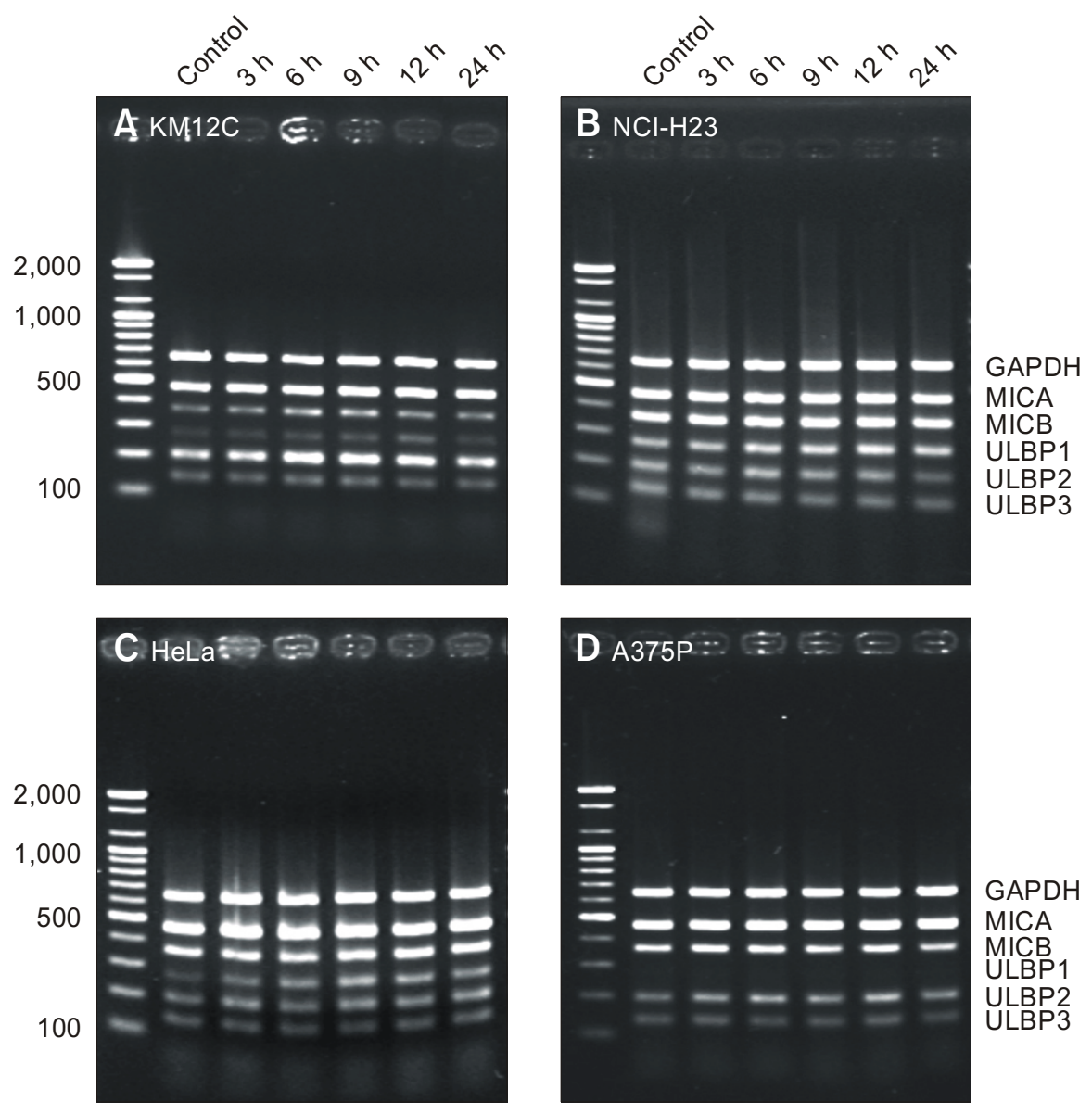

Figure 2. Induction of NKG2D ligands in human cancer cell lines by ionizing radiation. Each human cancer cell line was treated with ionizing radiation (exposure to $20 \mathrm{~Gy}$ ) and allowed to recover at $37^{\circ} \mathrm{C}$ for the indicated time. Total RNA was isolated and then subjected to multiplex RT-PCR analysis for expression of NKG2D ligands. (A) $\mathrm{KM} 12,(\mathrm{~B}) \mathrm{NCl}-\mathrm{H} 23$, (C) HeLa and (D) A375 cells.

A

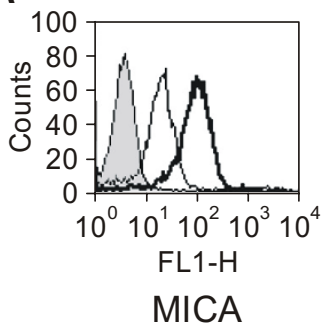

B

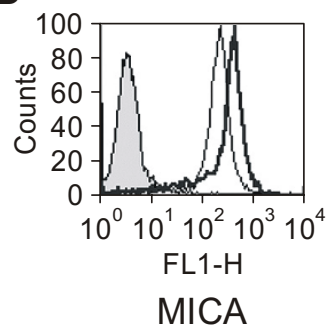

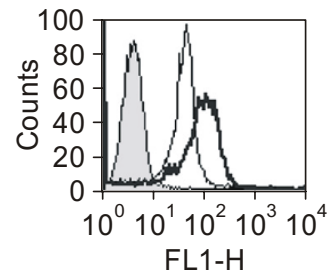

MICB

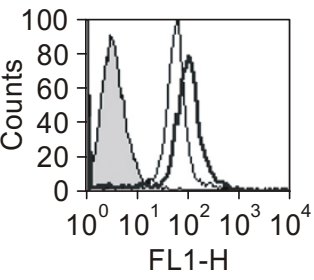

MICB

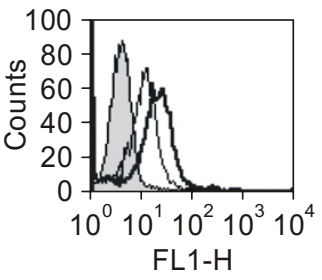

ULBP1

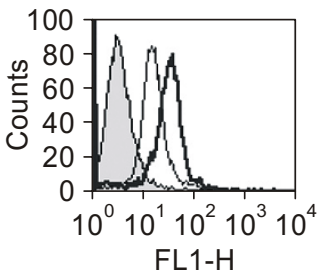

ULBP1
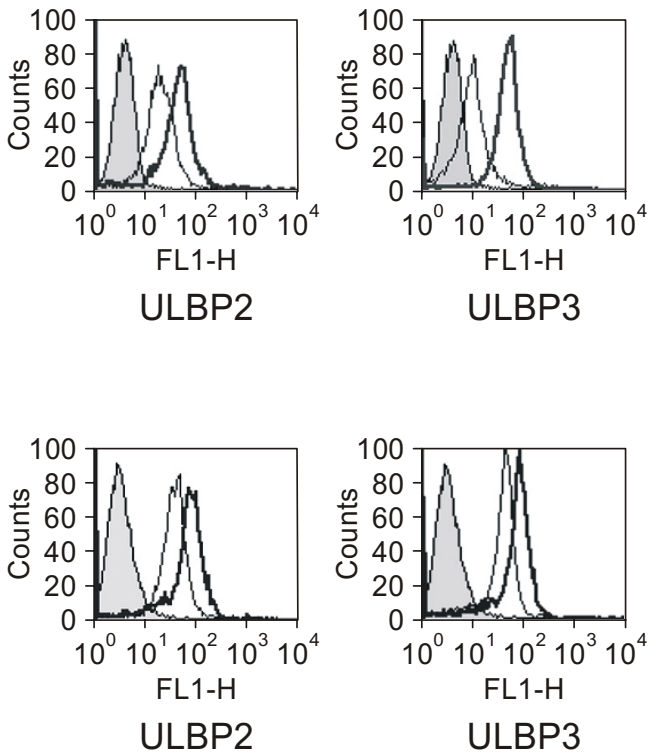

Figure 3. Surface expression of NKG2D ligands after heat shock treatment and ionizing radiation. NCl-H23 (A) and HeLa (B) cells were treated with heat shock and ionizing radiation as indicated in legend of Figure 1 and Figure 2, respectively. Flow cytometric analyses using anti-NKG2D ligands mAb were shown at 4 and $24 \mathrm{~h}$ after treatment with heat shock and ionizing radiation, respectively. Gray histograms, thin lines and thick lines showed isotype controls, untreated controls and treated cells, respectively. 

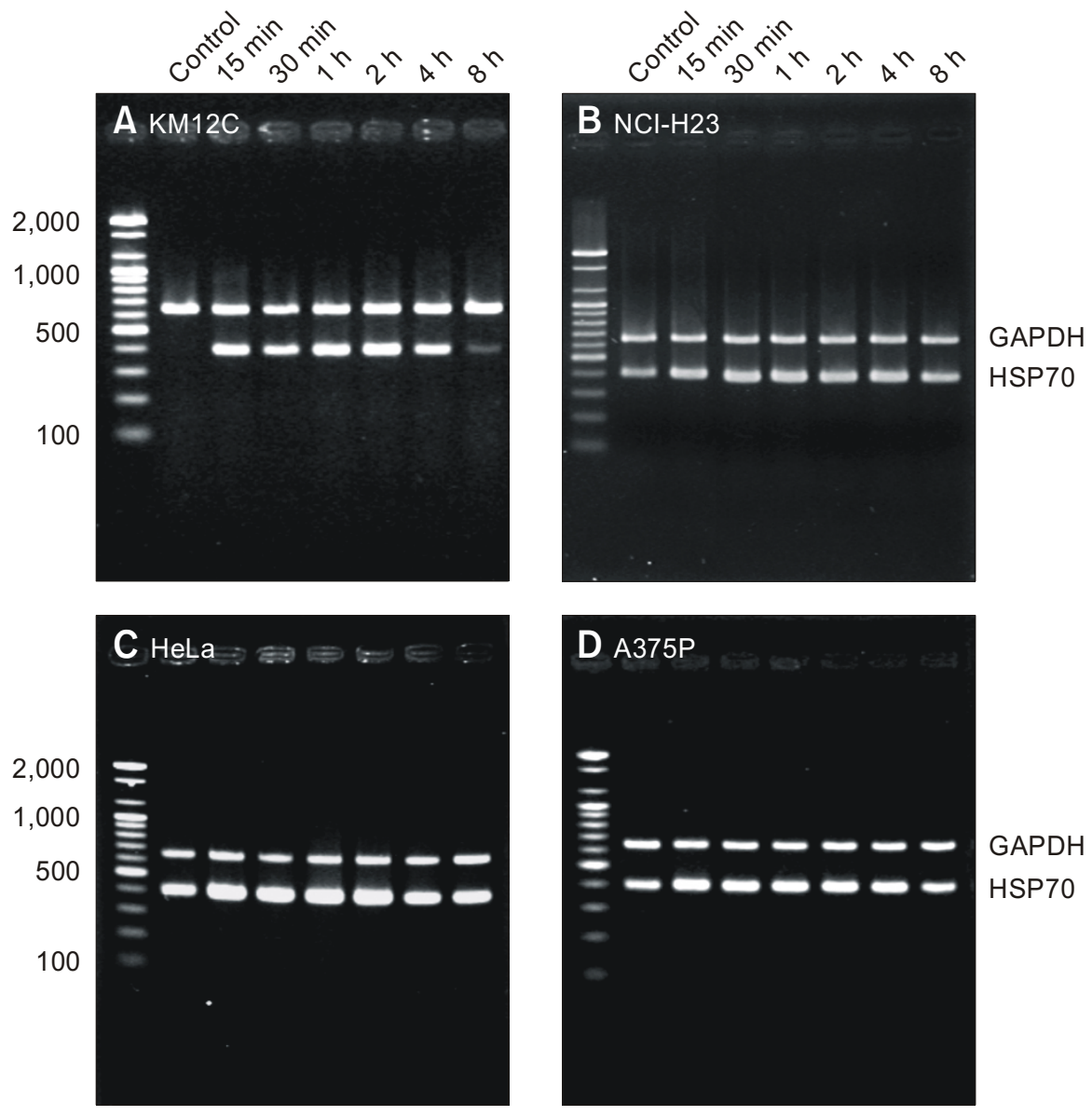

Figure 4. Expression of HSP70 in human cancer cell lines after heat shock treatment. Each human cancer cell line was treated with heat shock $(1 \mathrm{~h}$ exposure to $42^{\circ} \mathrm{C}$ ), and allowed to recover at $37^{\circ} \mathrm{C}$ for the indicated time. Total RNA was isolated and then subjected to RT-PCR analysis for expression of HSP70 (398 bp). (A) KM12, (B) NClH23, (C) HeLa and (D) A375 cells.

accompanied by the increased surface expression.

\section{Effect of heat shock and ionizing radiation on expression of HSP 70}

Since it has been known that heat shock treatment induces the expression of MICA/B, which are regulated by promoter heat shock elements similar to those of HSP70 genes (Groh et al., 1996), it was investigated whether heat shock and ionizing radiation can induce the expression of HSP70 in human cancer cell lines during the induction of NKG2D ligands. In this experiment, HSP70 was induced by heat shock (Figure 4), but not by ionizing radiation (Figure 5 ) in all tumor cells. The induction kinetics of NKG2D ligands and HSP70 were consistent with each other. These results suggest that the expression of NKG2D ligands may be regulated by complex stress signals as well as heat shock factors.

\section{Effect of heat shock and ionizing radiation on NK} cell-mediated cytotoxicity against tumor cells

It was examined if heat shock and ionizing radiation treatment can lead to increased sensitivity to NK cell-mediated cytotoxicity in tumor cells (Figure 6). After heat shock, the susceptibility to NK cells was significantly increased in KM12 cells, but not in other cells including $\mathrm{NCl}-\mathrm{H} 23$, HeLa and A375 cells. Meanwhile, after ionizing radiation, the susceptibility to NK cells was significantly increased in all cell lines except A375 cells. These results indicated that the sensitivity of tumor cells to NK cell-mediated cytotoxicity can be increased by both heat shock and ionizing radiation treatment, although it was dependent on cell types.

\section{Discussion}

Since recent findings illustrated that NK cell activation via NKG2D receptor can occur despite the normal expression of MHC class I molecules on the target cells (Cerwenka et al., 2000; Diefenbach et al., 2000; O'Connor et al., 2006), stress-induced upregulation of NKG2D ligands in tumor cells may trigger an additional signal towards activation and induction of NK cell-mediated cytolysis (Biassoni et 

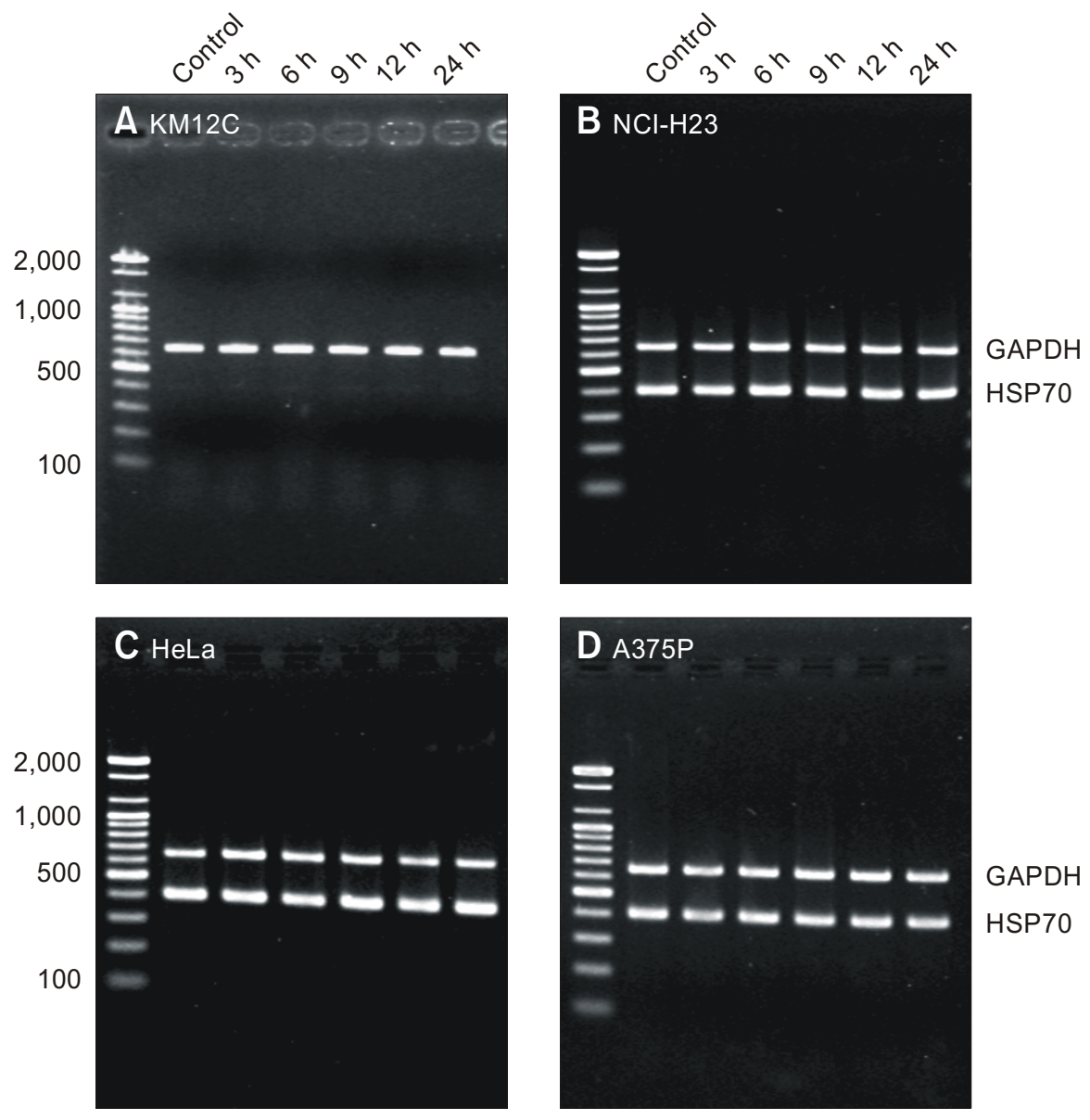

Figure 5. Expression of HSP70 in human cancer cell lines after ionizing radiation. Each human cancer cell line was treated with ionizing radiation (exposure to $20 \mathrm{~Gy}$ ) and allowed to recover at $37^{\circ} \mathrm{C}$ for the indicated time. Total RNA was isolated and then subjected to RT-PCR analysis for expression of HSP70 (398 bp). (A) KM12, (B) $\mathrm{NCl}-\mathrm{H} 23$, (C) HeLa and (D) A375 cells. al., 2003). Here, we have shown that heat shock upregulated expression of ULBPs and ionizing radiation increased the expression of NKG2D ligands in various human cancer cell lines, and consequently increased their susceptibility to NK cell-mediated cytotoxicity.

In the present study, heat shock and ionizing radiation appeared to increase $M I C A / B$ in various tumor cells, although sensitivities to the stresses were different among various cell lines. Previous report has shown that heat shock treatment results in increased mRNA and protein expression of MICA/B, which is presumably due to the presence of putative heat shock-elements in the 5'-flanking region of the corresponding genes (Groh et al., 1996). It has been known that HSP70 can be induced transcriptionally by various forms of stress including lethal heat shock, anoxia, heavy metals, UV radiation, gamma-rays and chemicals that cause DNA damage (Matsumoto et al., 1995; Santoro, 2000). However, in our study, the induction of MICA/B by ionizing radiation was not followed by induction of HSP70, suggesting that the expression of MIC genes may be regulated by other trans- cription factors as well as heat shock factors. Recently, it has been shown that mouse and human NKG2D ligands are upregulated by genotoxic stress, and ligand upregulation is prevented by pharmacological or genetic inhibition of ATR (ATM- and Rad3-related), ATM (ataxia telangiectasia, mutated) or Chk1 (a downstream transducer kinase in the pathway) (Gasser et al., 2005), and glycogen synthase kinase-3 activity is essential for the MICA/B expression induced by HDAC inhibitors (Skov et al., 2005).

ULBPs have been known to be induced by viral infection (Welte et al., 2003). We showed that ULBPs were induced also by both heat shock and ionizing radiation. Recently, it has been shown that ULBP1 and 2 clearly induce stronger signaling responses than ULBP3 (Kubin et al., 2001; Sutherland et al., 2002). Since both heat shock and ionizing radiation upregulated mainly the expression of ULBP1 and 2 on tumor cells, those treatments may provide benefits to NK cell-based immunotherapy. Since the transcriptional regulation of ULBPs have not been studied in detail currently, it is not known how ULBPs were upregulated by heat shock and ionizing ra- 
A

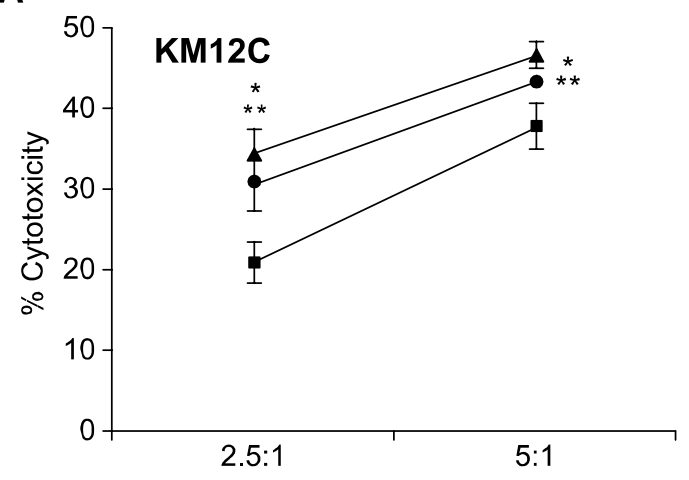

C

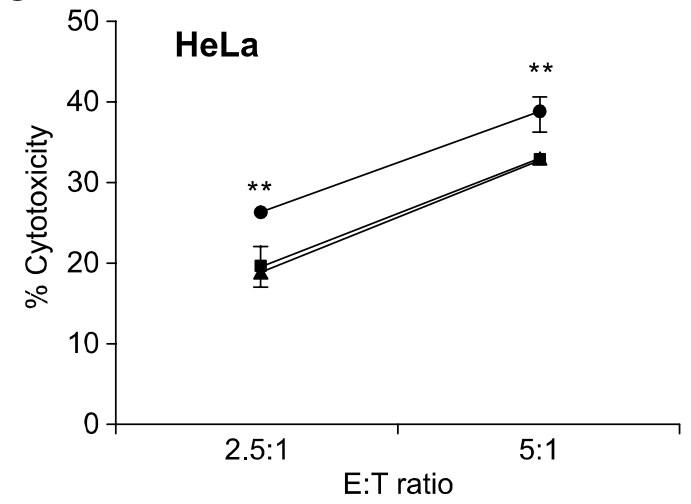

B

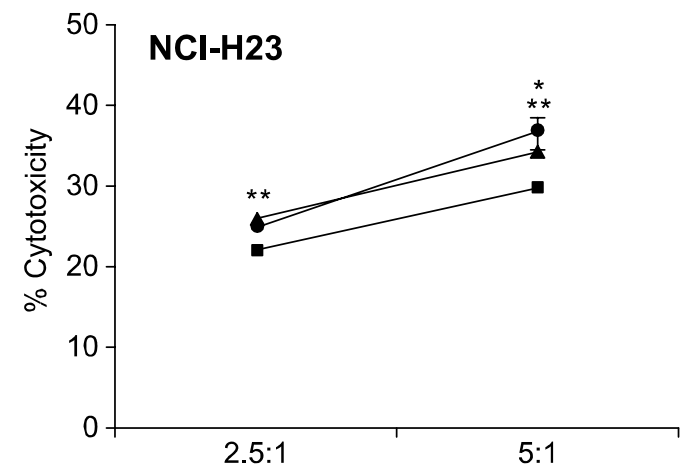

D

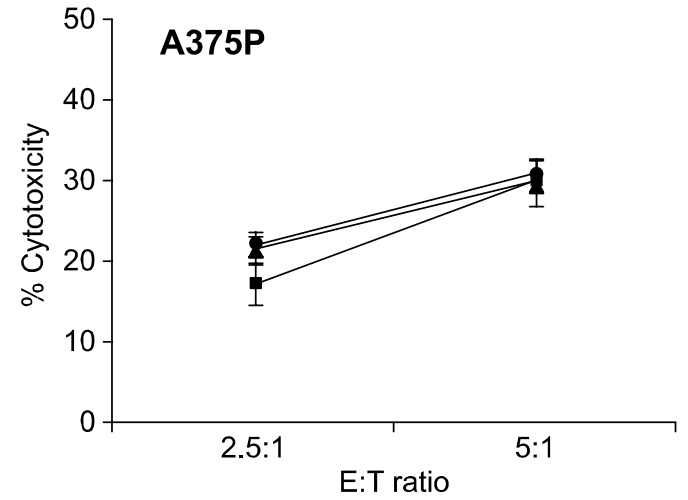

Figure 6. NK cell-mediated cytotoxicity against heat shock- or ionizing radiation-treated target tumor cells. ${ }^{51} \mathrm{Cr}$-labeled target cells (A, KM12; B, NCl-H23; C, HeLa; and D, A375 cells) were incubated with NK cells at the indicated effector/target ratios. Data from three independent experiments were presented as the average cytotoxicity \pm SE after subtraction of the cytotoxicity induced by heat shock or ionizing irradiation from the values of NK cell-mediated cytotoxicity against heat-shocked or irradiated target cells (square, untreated target cells; circle, irradiated target cells; and triangle, heat-shocked target cells). * and ${ }^{* *}(P<0.05)$ indicated the significant differences of the cytotoxicity against heat-shocked (triangle) and irradiated (circle) target cells compared with the cytotoxicity against untreated control (square), respectively.

diation. Recently, it has been suggested that the expression of ULBPs would be regulated at least by DNA damage pathways (Groh et al., 1996; Gasser et al., 2005).

A comparative sequence analysis of NKG2D ligand gene putative promoter regions demonstrated that there is significant sequence diversity, promoters of some NKG2D ligand genes are polymorphic, and several sequence alterations in these alleles abolish putative transcription factor binding (Eagle et al., 2006). Therefore, difference in availability of signaling molecules and transcription factors in different cell types may determine the differential expression of NKG2D ligands in various cells and cell typespecific response to heat shock and ionizing radiation. However, further studies are needed to determine the precise mechanisms by which heat shock and ionizing radiation activate NKG2D ligands including MICA/B and ULBPs.
In the present study, these results were followed in some tumor cells by increase of NK cell-mediated cytotoxicity after treatment of malignant tumor cells with heat shock or ionizing radiation. Previously, there were some reports showing that the susceptibility of tumor cells to lysis by lymphokine-activated killer cells (LAK) was significantly increased by hyperthermia (Strauch et al., 1994; Fujieda et al., 1995). The mechanisms of these effects have been suggested to be related to an increased trafficking of immune active cells to the tumor-bearing sites, an increase in the sensitivity of tumor cells to lysis, a local release of cytokines induced by hyperthermia, or de novo protein synthesis in heat-treated tumor cells. According to our study, the induction of NKG2D ligands appeared to contribute additionally to the enhanced susceptibility of heat-shocked tumor cells to NK cells. NKG2D ligands may be included in the proteins, which are needed to be synthesized de 
novo for susceptibility to LAK.

Radiation has been known to have immune modulating activities through upregulating expression of immunomodulatory surface molecules (MHC, costimulatory molecules, adhesion molecules, death receptors, heat shock proteins) and secretory molecules (cytokines, inflammatory mediators) in tumor, stromal, and vascular endothelial cells (Friedman, 2002). Recently, it has been shown that irradiation to malignant tumor cells enhanced killer cell-mediated cytotoxicity in autologous models (Ishikawa et al., 2004). This effect might be in part due to the upregulation of NKG2D ligands induced by ionizing radiation.

It has been mentioned that NK cells inhibit activity by themselves on recognition of HLA-class I on target cells (Moretta et al., 1993; Gumperz and Parham, 1995). Previously, some reports have shown that heat shock and high doses of gamma irradiation (i.e., 50 to $100 \mathrm{~Gy}$ ) increased MHC class I antigen on the surface of tumor cells 1-2 day after treatment (Santin et al., 1996; Ito et al., 2001). In the present study, the expression of HLA class I molecules was not changed up to $12 \mathrm{~h}$ by both heat shock and ionizing radiation in all cell lines used in this study (data not shown). These results demonstrated that the NK cell-mediated cytotoxicity stimulated by heat shock and ionizing radiation was not affected by modulation of HLA class I molecules during the cytotoxicity assay time (data not shown). However, if clinical application of combination of heat shock or ionizing radiation with NK cell-based immunotherapy will be considered, the induction of NKG2D ligands and HLA class I molecules may need to be monitored after heat shock or ionizing radiation in cancer patients.

There are many evidences showing that hyperthermia and ionizing radiation induce specific antitumor immunity (Friedman, 2002; Hildebrandt et al., 2002; Chakraborty et al., 2004; Manjili et al., 2004). Recently, intratumoral injection of dendritic cells, a professional antigen presenting cells, into locally heated or irradiated tumor have been shown to enhance specific antitumor immunity (Kim et al., 2004b; Chen et al., 2005; Tanaka et al., 2005). According to our experiment, NK cells may be injected into locally heated or irradiated tumors to induce antitumor immunity. However, since somewhat high dose of ionizing radiation was required to induce NKG2D ligands in various cell lines, radiosensitization by combination with hyperthermia or other methods may be required to improve the efficacy of NKG2D ligands induction (Chin et al., 2005; Song et al., 2005).

In conclusion, this study indicates that the heat shock and ionizing radiation induced NKG2D ligands in various cancer cells and might lead to increased NK cell-mediated cytotoxicity. Based on these results, clinical trials using local radiotherapy or hyperthermia combined with NK cell-based immunotherapy can be designed.

\section{Acknowledgement}

This work was supported by the MRC program of MOST/KOSEF (R13-2005-009).

\section{References}

Albertsson PA, Basse PH, Hokland M, Goldfarb $\mathrm{RH}$, Nagelkerke JF, Nannmark U, Kuppen PJ. NK cells and the tumour microenvironment: implications for NK-cell function and anti-tumour activity. Trends Immunol 2003;24:603-9

Amiot L, Onno M, Lamy T, Dauriac C, Le Prise PY, Fauchet R, Drenou B. Loss of HLA molecules in B lymphomas is associated with an aggressive clinical course. $\mathrm{Br} \mathrm{J}$ Haematol 1998;100:655-63

Biassoni R, Cantoni C, Marras D, Giron-Michel J, Falco M, Moretta L, Dimasi N. Human natural killer cell receptors: insights into their molecular function and structure. J Cell Mol Med 2003;7:376-87

Cerwenka A, Bakker AB, McClanahan T, Wagner J, Wu J, Phillips JH, Lanier LL. Retinoic acid early inducible genes define a ligand family for the activating NKG2D receptor in mice. Immunity 2000;12:721-7

Chakraborty M, Abrams SI, Coleman CN, Camphausen K, Schlom J, Hodge JW. External beam radiation of tumors alters phenotype of tumor cells to render them susceptible to vaccine-mediated T-cell killing. Cancer Res 2004;64:4328-37

Chen Z, Xia D, Bi X, Saxena A, Sidhu N, El-Gayed A, Xiang $J$. Combined radiation therapy and dendritic cell vaccine for treating solid tumors with liver micro-metastasis. J Gene Med 2005;7:506-17

Chin C, Bae JH, Kim MJ, Hwang JY, Kim SJ, Yoon MS, Lee MK, Kim DW, Chung BS, Kang CD, Kim SH. Radiosensitization by targeting radioresistance-related genes with protein kinase $A$ inhibitor in radioresistant cancer cells. Exp Mol Med 2005; 37:608-18

Colucci F, Caligiuri MA, Di Santo JP. What does it take to make a natural killer? Nat Rev Immunol 2003;3:413-25

Diefenbach A, Jamieson AM, Liu SD, Shastri N, Raulet DH. Ligands for the murine NKG2D receptor: expression by tumor cells and activation of NK cells and macrophages. Nat Immunol 2000;1:119-26

Eagle RA, Traherne JA, Ashiru O, Wills MR, Trowsdale J. Regulation of NKG2D ligand gene expression. Hum Immunol 2006;67:159-69

Farag SS, Fehniger TA, Becknell B, Blaser BW, Caligiuri MA. New directions in natural killer cell-based immunotherapy of human cancer. Expert Opin Biol Ther 2003;3:237-50

Farag SS, Caligiuri MA. Human natural killer cell development 
and biology. Blood Rev 2006;20:123-37

Friedman EJ. Immune modulation by ionizing radiation and its implications for cancer immunotherapy. Curr Pharm Des 2002;8:1765-80

Fujieda S, Noda I, Saito H, Hoshino T, Yagita M. Heat shock enhances the susceptibility of tumor cells to lysis by lymphokine-activated killer cells. Arch Otolaryngol Head Neck Surg 1995;121:1009-14

Gasser S, Orsulic S, Brown EJ, Raulet DH. The DNA damage pathway regulates innate immune system ligands of the NKG2D receptor. Nature 2005;436:1186-90

Groh V, Bahram S, Bauer S, Herman A, Beauchamp M, Spies T. Cell stress-regulated human major histocompatibility complex class I gene expressed in gastrointestinal epithelium. Proc Natl Acad Sci USA 1996;93:12445-50

Groh V, Steinle A, Bauer S, Spies T. Recognition of stress-induced MHC molecules by intestinal epithelial gammadelta T cells. Science 1998;279:1737-40

Gumperz JE, Parham P. The enigma of the natural killer cell. Nature 1995;378:245-8

Hildebrandt B, Wust P, Ahlers O, Dieing A, Sreenivasa G, Kerner T, Felix R, Riess $\mathrm{H}$. The cellular and molecular basis of hyperthermia. Crit Rev Oncol Hematol 2002;43:33-56

Ishikawa E, Tsuboi K, Saijo K, Takano S, Ohno T. X-irradiation to human malignant glioma cells enhances the cytotoxicity of autologous killer lymphocytes under specific conditions. Int J Radiat Oncol Biol Phys 2004;59:1505-12

Ito A, Shinkai M, Honda H, Wakabayashi T, Yoshida J, Kobayashi T. Augmentation of MHC class I antigen presentation via heat shock protein expression by hyperthermia. Cancer Immunol Immunother 2001;50:515-22

Kim A, Noh YW, Kim KD, Jang YS, Choe YK, Lim JS. Activated natural killer cell-mediated immunity is required for the inhibition of tumor metastasis by dendritic cell vaccination. Exp Mol Med 2004a;36:428-43

Kim KW, Kim SH, Shin JG, Kim GS, Son YO, Park SW, Kwon $\mathrm{BH}$, Kim DW, Lee CH, Sol MY, Jeong MH, Chung BS, Kang CD. Direct injection of immature dendritic cells into irradiated tumor induces efficient antitumor immunity. Int J Cancer 2004b; 109:685-90

Kubin M, Cassiano L, Chalupny J, Chin W, Cosman D, Fanslow W, Mullberg J, Rousseau AM, Ulrich D, Armitage R. ULBP1, 2, 3: novel MHC class I-related molecules that bind to human cytomegalovirus glycoprotein UL16, activate NK cells. Eur J Immunol 2001;31:1428-37

Manjili MH, Wang XY, MacDonald IJ, Arnouk H, Yang GY, Pritchard MT, Subjeck JR. Cancer immunotherapy and heat-shock proteins: promises and challenges. Expert Opin Biol Ther 2004;4:363-73

Matsumoto $\mathrm{H}$, Wang $\mathrm{X}$, Ohnishi T. Binding between wild-type p53 and hsp72 accumulated after UV and gamma-ray irradiation. Cancer Lett 1995;92:127-33

Moretta A, Vitale M, Bottino C, Orengo AM, Morelli L, Augugliaro R, Barbaresi M, Ciccone E, Moretta L. P58 molecules as putative receptors for major histocompatibility complex
(MHC) class I molecules in human natural killer (NK) cells. Anti-p58 antibodies reconstitute lysis of MHC class I-protected cells in NK clones displaying different specificities. J Exp Med 1993;178:597-604

O'Connor GM, Hart OM, Gardiner CM. Putting the natural killer cell in its place. Immunology 2006;117:1-10

Park SW, Bae JH, Kim SD, Son YO, Kim JY, Lee CH, Park DY, Kim JY, Lee MK, Chung BS, Kim SH, Kang CD. Comparison of NKG2D ligands between normal and tumor tissue determined with newly developed multiplex RT-PCR. Cancer Invest In press

Pawelec G. Tumour escape: antitumour effectors too much of a good thing? Cancer Immunol Immunother 2004;53:262-74

Raulet DH. Roles of the NKG2D immunoreceptor and its ligands. Nat Rev Immunol 2003;3:781-90

Rosenberg SA. A new era for cancer immunotherapy based on the genes that encode cancer antigens. Immunity $1999 ; 10: 281-7$

Santin AD, Hiserodt JC, Fruehauf J, DiSaia PJ, Pecorelli S, Granger GA. Effects of irradiation on the expression of surface antigens in human ovarian cancer. Gynecol Oncol 1996; 60:468-74

Santin $A D$, Hermonat $P L$, Ravaggi $A$, Chiriva-Internati $M$, Hiserodt JC, Batchu RB, Pecorelli S, Parham GP. The effects of irradiation on the expression of a tumour rejection antigen (heat shock protein gp96) in human cervical cancer. Int J Radiat Biol 1998;73:699-704

Santoro MG. Heat shock factors and the control of the stress response. Biochem Pharmacol 2000;59:55-63

Skov S, Pedersen MT, Andresen L, Straten PT, Woetmann A, Odum N. Cancer cells become susceptible to natural killer cell killing after exposure to histone deacetylase inhibitors due to glycogen synthase kinase-3-dependent expression of MHC class I-related chain A and B. Cancer Res 2005;65:11136-45

Smyth MJ, Hayakawa Y, Takeda K, Yagita H. New aspects of natural-killer-cell surveillance and therapy of cancer. Nat Rev Cancer 2002;2:850-61

Song CW, Park HJ, Lee CK, Griffin R. Implications of increased tumor blood flow and oxygenation caused by mild temperature hyperthermia in tumor treatment. Int J Hyperthermia 2005; 21:761-7

Strauch ED, Fabian DF, Turner J, Lefor AT. Combined hyperthermia and immunotherapy treatment of multiple pulmonary metastases in mice. Surg Oncol 1994;3:45-52

Sutherland CL, Chalupny NJ, Schooley K, VandenBos T, Kubin M, Cosman D. UL16-binding proteins, novel MHC class I-related proteins, bind to NKG2D and activate multiple signaling pathways in primary NK cells. J Immunol 2002; 168:671-9

Tanaka K, Ito A, Kobayashi T, Kawamura T, Shimada S, Matsumoto K, Saida T, Honda H. Intratumoral injection of immature dendritic cells enhances antitumor effect of hyperthermia using magnetic nanoparticles. Int J Cancer 2005; 116:624-33

Vivier E, Tomasello E, Paul P. Lymphocyte activation via 
NKG2D: towards a new paradigm in immune recognition? Curr Opin Immunol 2002;14:306-11

Watzl C. The NKG2D receptor and its ligands-recognition beyond the "missing self"? Microbes Infect 2003;5:31-7
Welte SA, Sinzger C, Lutz SZ, Singh-Jasuja H, Sampaio KL, Eknigk U, Rammensee HG, Steinle A. Selective intracellular retention of virally induced NKG2D ligands by the human cytomegalovirus UL16 glycoprotein. Eur J Immunol 2003; 33:194-203 